Strelbytska I., Hudyma A. Dynamics of endogenous intoxication indicators in condition of acute blood loss complicated by ischemiareperfusion of the limb, and their correction by carbacetam. Journal of Education, Health and Sport. 2020;10(12):394-405. eISSN 2391-8306. DOI http://dx.doi.org/10.12775/JEHS.2020.10.12.039

https://apcz.umk.pl/czasopisma/index.php/JEHS/article/view/JEHS.2020.10.12.039

https://zenodo.org/record/5153989

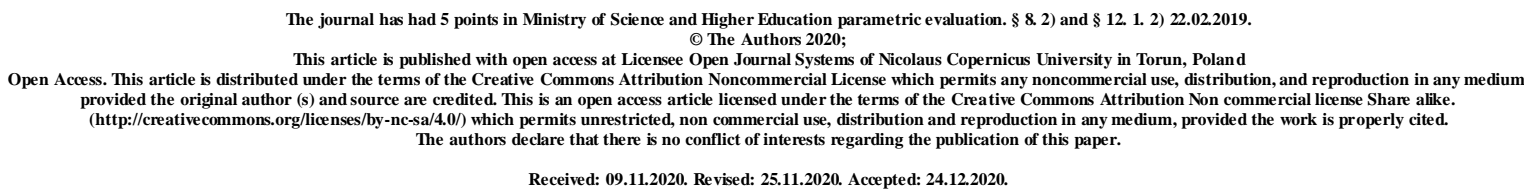

UDK 616-008.6:616.748-005.1/-005.4]-085.214.3-092.9

\title{
DYNAMICS OF ENDOGENOUS INTOXICATION INDICATORS IN CONDITION OF ACUTE BLOOD LOSS COMPLICATED BY ISCHEMIA-REPERFUSION OF THE LIMB, AND THEIR CORRECTION BY CARBACETAM
}

\author{
I. V. Strelbytska, A. A. Hudyma
}

\section{Ivan Horbachevsky Ternopil National Medical University Ministry of Health of Ukraine}

\section{Abstract}

Introduction. In the structure of injuries from gunshot wounds dominate the limb injuries that are often complicated by massive bleeding from the main vessels. The only means of rescue on the battlefield is a timely application of a tourniquet. This ensures complete exsanguination of the limb. The duration of exsanguination should not exceed 2 hours. It is proved that in conditions of acute blood loss complicated by ischemia-reperfusion of the limb, there are prerequisites for the development of dysfunction of internal organs, which in turn exacerbates dysmetabolic and functional disorders, stimulates endotoxicosis and may be complicated by multiple organ failure. However, the patterns of formation of the syndrome of endogenous intoxication in the conditions of ischemia-reperfusion of the limb, acute blood loss and their combinations have not been studied. There are no data on the effect of Carbacetam on these processes. It is known that Carbacetam has proven itself to reduce the manifestations of dysfunction of internal organs in the conditions of ischemic-reperfusion syndrome of the limb. 
The objective of research: To establish the dynamics of endogenous intoxication in the conditions of ischemia-reperfusion of the limb, acute blood loss and their combination. To evaluate the effectiveness of Carbacetam in the correction of identified abnormalities.

Materials and methods. The experimental studies were conducted on 108 white nonlinear male rats weighing 200-220 g, which were housed in standard vivarium conditions. All animals were divided into five groups: control and four experimental. Under thiopentalsodium anesthesia in the first experimental group was simulated ischemia-reperfusion of the limb, in the second - acute blood loss, and in the third - these injuries were combined. In the fourth experimental group, animals with acute blood loss and ischemia-reperfusion of the limb were intraperitoneally administered Carbacetam at a dose of $5 \mathrm{mg}$ per kilogram of animal weight. After 1 and 2 hours, as well as after 1, 7 and 14 days in the blood serum was determined the content of middle-mass molecules $\left(\mathrm{MMM}_{254}, \mathrm{MMM}_{280}\right)$.

The results and discussion. It was found that ischemia-reperfusion of the limb in comparison with the control group is accompanied by a significant increase of the $\mathrm{MMM}_{254}$ fraction in the blood serum content. From the first hour of the experiment with a maximum after 1 day and normalization of the index up to 14 days. The content in the blood serum of the $\mathrm{MMM}_{280}$ fraction became significantly higher, from the control only after 1 day with subsequent normalization in the following terms of the experiment. After simulation of acute blood loss, both studied fractions of MMM increased from 1 hour of the experiment, reached a maximum after 1 day and did not return to the control level after 14 days. For the first time it was found that two-hour ischemia-reperfusion of the limb significantly aggravates the course of acute blood loss, which revealed a significantly higher content in the serum of fractions $\mathrm{MMM}_{254}$ and $\mathrm{MMM}_{280}$ compared to other experimental groups in almost all periods of the experiment. Due to the use of Carbacetam, the content of both studied fractions of MMM in the serum compared with animals without correction was significantly reduced after 7 and 14 days of the experiment. Although the studied parameters did not return to the level of the Carbacetam control group, it can be considered a pathogenetically justified means of reducing the level of endotoxicosis in the conditions of ischemia-reperfusion of the limb and acute blood loss.

Conclusions. Simulation of limb ischemia-reperfusion is accompanied by accumulation of $\mathrm{MMM}_{254-280}$ fractions with a maximum after 1 day of the experiment and normalization up to 14 days. Acute blood loss causes an increase in the serum content of fractions $\mathrm{MMM}_{254-280}$ from 1 hour of the experiment, which up to 14 days do not reach the level of control. The detected disorders are significantly exacerbated after a combination of 
acute blood loss and ischemia-reperfusion of the limb. The use of Carbacetam in comparison with animals without correction is accompanied by a significant decrease in the content of $\mathrm{MMM}_{254-280}$ fractions in the serum after 7 and 14 days of the experiment.

Key words: blood loss; ischemia-reperfusion of the limb; endotoxicosis; average molecular weight (MMM); Carbacetam.

Introduction. The frequency of local armed conflicts and terrorist attacks has increased significantly in recent years. In the structure of injuries from gunshot wounds dominate the limb injuries that often complicated by massive bleeding from the main vessels. The only means of salvation on the battlefield is a timely application of a tourniquet. This ensures complete exsanguination of the limb, the duration of which should not exceed 2 hours [1]. However, according to research by a number of authors, complete exsanguination of the limb for two hours can cause biochemical and structural disorders of soft tissues under the tourniquet and in the area of ischemia [2], which deepen after repefusion. According to [3], such disorders can lead to limb amputation, damage of nerves and blood vessels under the tourniquet, myonecrosis, limb compartment syndrome with the necessity of fasciotomy, rhabdomyolysis with the development of acute renal failure, thrombosis of deep veins and pulmonary artery, skin damage under the tourniquet with the development of an abscess. In the works of some authors it is noted that reperfusion of the ischemic limb after removal of the tourniquet and restoration of blood flow causes inflammation of damage-induced local areas. Inflammatory mediators and toxic metabolites, entering the systemic bloodstream, can adversely affect vital organs $[4,5]$. It is proved that under conditions of acute blood loss complicated by ischemia-reperfusion of the limb, there are prerequisites for the development of dysfunction of internal organs [6]. This exacerbates dysmetabolic and functional disorders, stimulates endotoxicosis and may be complicated by multiple organ failure. However, the patterns of formation of the syndrome of endogenous intoxication in the conditions of ischemia-reperfusion of the limb, acute blood loss and their combination have not been studied. There are no data on the effect of Carbacetam on these processes - a drug that has proven to reduce the manifestations of dysfunction of internal organs in the conditions of ischemic-reperfusion syndrome of the limb [7].

The objective of research: To find out the dynamics of endogenous intoxication in the conditions of ischemia-reperfusion of the limb, acute blood loss and their combination. To evaluate the effectiveness of Carbacetam in the correction of identified disorders. 


\section{Materials and methods}

The experimental studies were conducted on 108 white nonlinear male rats weighing 200-220 g, which were housed in standard vivarium conditions. All animals were divided into five groups: control and four experimental (each groups contained 6 rats).

All experiments were performed under thiopental sodium anesthesia ( $40 \mathrm{mg} \mathrm{kg}^{-1}$ body weight ) dosed. In the first experimental group were simulated ischemia-reperfusion of the limb. For this purpose, a strip of elastic tourniquet "SWAT-T" (USA) width of $10 \mathrm{~mm}$ was proximally applied to the left foot, which completely stopped the blood flow for 120 minutes. In the second experimental group, acute blood loss (20\% of the circulating blood volume) was simulated by crossing the femoral vein. In the third experimental group, these injuries were combined. In the fourth experimental group, animals with acute blood loss and ischemia-reperfusion of the limb intraperitoneally administered Carbacetam, for corrective purposes. Administered at a dose of $5 \mathrm{mg}$ per kilogram of animal weight. (L.M. Litvinenko Institute of Physical-Organic Chemistry and Coal Chemistry of the National Academy of Sciences of Ukraine, Kyiv) [8]. In the control group, the animals were only anesthetized using an equivalent dose of sodium thiopental.

After 1 and 2 hours, as well as after 1, 7 and 14 days under thiopentalone sodium anesthesia, the experimental animals were removed from the experiment by the method of total bloodletting from the heart. The content of endogenous intoxication products, namely the fractions of middle-mass molecules determined at 254 and $280 \mathrm{~nm}\left(\mathrm{MMM}_{254}, \mathrm{MMM}_{280}\right)$ was studied in blood serum [9].

All experimental procedures fulfilled the international standards for the humane treatment of animals in compliance with the regulations of «The European Convention for the protection of vertebrate animals used for experimental and other scientific purposes (European Convention, 1986)». The test animals were subsequently euthanized through complete exsanguination from the heart.

All obtained data were processed to the statistical analysis by the nonparametric The Mann-Whitney U test using STATISTICA 10.0 software («StatSoft Inc.», USA).

The results and discussion. As we can see from the table 1, under the influence of modeling only ischemia-reperfusion of the limb, the content of the $\mathrm{MMM}_{254}$ fraction in the serum was statistically significantly higher compared to the control after 1 hour of the experiment $(18.9 \%, \mathrm{p}<0.05)$. The indicator continued to grow and reached a maximum after 1 day (94.6\%, p<0.05), which was also significantly higher compared to 1 and 2 hours of the experiment (respectively 63.6 and $28.6 \%, \mathrm{p}<0,05$ ). Subsequently, the indicator remained at 
the same level for 1 day and after 7 days of the experiment ( $>0.05$ ). After 14 days, the content of the $\mathrm{MMM}_{254}$ fraction decreased, was statistically significantly lower compared to the result of 1 hour, 1 and 7 days $(p<0.05)$ and reached the level of the control group $(p>0.05)$.

Table 1 - Dynamics of the content of the fraction $\mathrm{MMM}_{254}$ in the blood serum after acute blood loss complicated by ischemia-reperfusion of the limb (Me (LQ; UQ) - median (lower and upper quartiles))

\begin{tabular}{|c|c|c|c|c|c|}
\hline \multirow{2}{*}{$\begin{array}{l}\text { Experimental } \\
\text { group }\end{array}$} & \multicolumn{5}{|c|}{ The term of the reperfusion period } \\
\hline & 1 hour & 2 hours & 1 day & 7 days & 14 days \\
\hline \multicolumn{6}{|c|}{ Control $=0,037(0,028 ; 0,038)(n=6)$} \\
\hline $\begin{array}{l}\text { Group 1 } \\
\text { Ischemia- } \\
\text { reperfusion }\end{array}$ & $\begin{array}{l}0,044^{*} \\
0,043 \\
0,046 \\
(\mathrm{n}=6)\end{array}$ & $\begin{array}{c}0,056^{* 1 \Gamma} \\
0,053 \\
0,058 \\
(\mathrm{n}=6)\end{array}$ & $\begin{array}{c}0,072 * 1 г, 2 г \\
0,067 ; 0,075 \\
(\mathrm{n}=6)\end{array}$ & $\begin{array}{c}0,064^{* 1 \Gamma} \\
0,059 \\
0,067 \\
(\mathrm{n}=6)\end{array}$ & 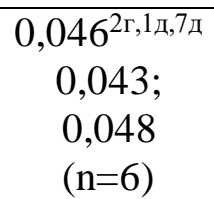 \\
\hline $\begin{array}{l}\text { Group } 2 \\
\text { Blood loss }\end{array}$ & $\begin{array}{l}0,062^{*} \\
0,059 \\
0,064 \\
(\mathrm{n}=6)\end{array}$ & $\begin{array}{c}0,084^{*} 1 \Gamma \\
0,080 \\
0,090 \\
(\mathrm{n}=6)\end{array}$ & $\begin{array}{c}0,125^{* 1 г, 2 г} \\
0,121 ; 0,128 \\
(n=6)\end{array}$ & $\begin{array}{c}0,104^{* 1 г, 2 г, 1 д} \\
0,096 \\
0,107 \\
(\mathrm{n}=6)\end{array}$ & $\begin{array}{c}0,086^{* 1 г, 1 д, 7 д ~} \\
0,079 \\
0,092 \\
(\mathrm{n}=6)\end{array}$ \\
\hline $\begin{array}{l}\text { Group } 3 \\
\text { Ischemia- } \\
\text { reperfusion }+ \\
\text { blood loss }\end{array}$ & $\begin{array}{l}0,086^{*} \\
0,079 \\
0,088 \\
(\mathrm{n}=6)\end{array}$ & $\begin{array}{c}0,098^{*} 1 \Gamma \\
0,092 \\
0,103 \\
(\mathrm{n}=6)\end{array}$ & $\begin{array}{c}0,149^{* 1 г, 2 г} \\
0,146 ; 0,156 \\
(n=6)\end{array}$ & $\begin{array}{c}0,122^{* 1 г, 2 г, 1 д} \\
0,119 \\
0,130 \\
(\mathrm{n}=6)\end{array}$ & $\begin{array}{c}0,109^{* 1 г, 1 д, 7 д ~} \\
0,105 ; \\
0,112 \\
(\mathrm{n}=6)\end{array}$ \\
\hline $\mathrm{p}_{1-2}$ & $<0,05$ & $<0,05$ & $<0,05$ & $<0,05$ & $<0,05$ \\
\hline $\mathrm{p}_{1-3}$ & $<0,05$ & $<0,05$ & $<0,05$ & $<0,05$ & $<0,05$ \\
\hline $\mathrm{p}_{2-3}$ & $<0,05$ & $>0,05$ & $<0,05$ & $<0,05$ & $<0,05$ \\
\hline
\end{tabular}

Notes. Here and in table. 2:

$1 .{ }^{*}$ - differences relative to the control group are statistically significant $(\mathrm{p}<0,05)$;

2. $\mathrm{p}_{1-2}$ - the probability of differences between experimental groups 1 and 2;

3. $\mathrm{p}_{1-3}$ - the probability of differences between experimental groups 1 and 3;

4. $\mathrm{p}_{2-3}$ - the probability of differences between experimental groups 2 and 3 .

Simulation of acute blood loss compared with the control was accompanied by a greater increase in serum $\mathrm{MMM}_{254}$ : after 1 hour - by $66.2 \%$, after 2 hours - by 2.27 times, after 1 day - by 3.38 times ( $\mathrm{p}<0,05$ ). Subsequently, the indicator decreased and after 7 days was statistically significantly lower compared to the result of 1 and 2 hours and 1 day of the experiment $(\mathrm{p}<0.05)$, but continued to be 2.81 times higher than in the control $(\mathrm{p}<0.05)$. By 14 days, the indicator became smaller and statistically significantly different from the result of 1 hour, 1 and 7 days of the experiment $(\mathrm{p}<0.05)$, but was 2.32 times higher than in the control $(\mathrm{p}<0.05)$. Acute blood loss caused a significantly lower level of $\mathbf{M M M}_{254}$ compared with the group were only ischemia-reperfusion of the limb was simulated at all observation times 
$\left(\mathrm{p}_{1-2}<0.05\right)$.

Table 2 - Dynamics of the content of the fraction $\mathrm{MMM}_{280}$ in the blood serum after acute blood loss complicated by ischemia-reperfusion of the limb (Me (LQ; UQ) - median (lower and upper quartiles))

\begin{tabular}{|c|c|c|c|c|c|}
\hline \multirow{2}{*}{$\begin{array}{l}\text { Experimental } \\
\text { group }\end{array}$} & \multicolumn{5}{|c|}{ The term of the reperfusion period } \\
\hline & 1 hour & 2 hours & 1 day & 7 days & 14 days \\
\hline \multicolumn{6}{|c|}{ Control $=0,033(0,029 ; 0,036)(n=6)$} \\
\hline $\begin{array}{l}\text { Group 1 } \\
\text { Ischemia- } \\
\text { reperfusion }\end{array}$ & $\begin{array}{l}0,036 \\
0,035 ; \\
0,038 \\
(n=6)\end{array}$ & $\begin{array}{l}0,038 \\
0,036 ; \\
0,041 \\
(\mathrm{n}=6)\end{array}$ & $\begin{array}{c}0,044^{*} \text { г } \\
0,041 ; 0,049 \\
(n=6)\end{array}$ & $\begin{array}{l}0,040 \\
0,037 ; \\
0,043 \\
(\mathrm{n}=6)\end{array}$ & $\begin{array}{l}0,034 \\
0,028 \\
0,039 \\
(\mathrm{n}=6)\end{array}$ \\
\hline $\begin{array}{l}\text { Group } 2 \\
\text { Blood loss }\end{array}$ & $\begin{array}{c}0,042^{*} \\
0,036 ; \\
0,044 \\
(n=6)\end{array}$ & $\begin{array}{c}0,059^{* 1} 1 \Gamma \\
0,057 \\
0,063 \\
(n=6)\end{array}$ & $\begin{array}{c}0,071^{*} 1_{\Gamma, 2 \Gamma} \\
0,069 \\
0,074 \\
(\mathrm{n}=6)\end{array}$ & $\begin{array}{c}0,068^{*} 1 \mathrm{1}, 2 \text { г } \\
0,067 \\
0,073 \\
(\mathrm{n}=6)\end{array}$ & $\begin{array}{c}0,061^{* 1 г, 1 д} \\
0,054 ; \\
0,065 \\
(\mathrm{n}=6)\end{array}$ \\
\hline $\begin{array}{l}\text { Group } 3 \\
\text { Ischemia- } \\
\text { reperfusion } \\
+ \text { blood loss }\end{array}$ & $\begin{array}{l}0,044^{*} \\
0,041 ; \\
0,046 \\
(\mathrm{n}=6)\end{array}$ & $\begin{array}{c}0,066^{* 1} 1 \text { г } \\
0,060 \\
0,070 \\
(n=6)\end{array}$ & $\begin{array}{c}0,098^{*} 1 г, 2 \Gamma \\
0,096 \\
0,104 \\
(n=6)\end{array}$ & $\begin{array}{c}0,089^{*} 1 \mathrm{r}, 2 \mathrm{r} \\
0,080 \\
0,096 \\
(\mathrm{n}=6)\end{array}$ & $\begin{array}{c}0,075^{* 1 г, 1 д} \\
0,073 \\
0,081 \\
(\mathrm{n}=6)\end{array}$ \\
\hline $\mathrm{p}_{1-2}$ & $>0,05$ & $<0,05$ & $<0,05$ & $<0,05$ & $<0,05$ \\
\hline $\mathrm{p}_{1-3}$ & $<0,05$ & $<0,05$ & $<0,05$ & $<0,05$ & $<0,05$ \\
\hline $\mathrm{p}_{2-3}$ & $>0,05$ & $>0,05$ & $<0,05$ & $<0,05$ & $<0,05$ \\
\hline
\end{tabular}

The combination of limb ischemia-reperfusion and acute blood loss caused the largest violations of the content of the $\mathrm{MMM}_{254}$ fraction in the serum. In the all terms of the experiment the indicator was statistically significantly lower than in the control $(\mathrm{p}<0.05)$ and compared with other experimental groups $\left(\mathrm{p}_{1-3}<0,05, \mathrm{p}_{2-3}<0,05\right)$. In the dynamics, the indicator reached a maximum after 1 day (4.03 times higher than the control group and 1 and 2 goals of the experiment, $p<0.05$ ) and decreased by 14 days ( $p<0.05$ compared with 1 hour, 1 and 7 days experiment). During this period, the indicator continued to exceed the level of control by 2.93 times $(\mathrm{p}<0.05)$.

Also, the content of the $\mathrm{MMM}_{280}$ fraction in the serum under the influence of simulation of ischemia-reperfusion of the limb was characterized by less violations than the content of the fraction $\mathrm{MMM}_{254}$. Only after 1 day of the experiment, the index became statistically significantly smaller compared to the control (by $31.8 \%, \mathrm{p}<0.05$ ), and later normalized.

After simulation of acute blood loss, the content of the $\mathrm{MMM}_{280}$ fraction in the serum from 1 hour of the experiment compared with the control increased (by $25.8 \%, \mathrm{p}<0,05$ ). The 
indicator reached a maximum in 1 day and in this period exceeded the control by 2.15 times $(\mathrm{p}<0.05)$ and the result of 1 and 2 hours of observation $(\mathrm{p}<0.05)$. By day 14 , the rate decreased, becoming significantly less than after 1 hour and 1 day of the experiment $(p<0.05)$, but continued to exceed the control by $54.8 \%(\mathrm{p}<0.05)$.

After simulation of acute blood loss in combination with ischemia-reperfusion of the limb the content of the $\mathrm{MMM}_{280}$ fraction in the blood serum after 1 hour increased by $31.8 \%$, after 2 hours -2.00 times, after 1 day -2.96 times $(\mathrm{p}<0.05)$. Subsequently, the indicator decreased and after 14 days was significantly less than after 1 hour and 2 days of the experiment $(\mathrm{p}<0.05)$, but 2.27 times higher than the control $(\mathrm{p}<0.05)$.

Comparison of the experimental groups showed that after 1 hour of the experiment, the content of the $\mathrm{MMM}_{280}$ fraction in the blood serum was significantly lower in experimental group 3, compared with experimental group 1 (22.2 \%, $\left.\mathrm{p}_{1-3}<0.05\right)$. After 2 hours of the experiment, the indicator was significantly higher in experimental groups 2 and 3 compared with experimental group 1 (respectively, $55.3 \%, \mathrm{p}_{1-2}<0.05$ and $73.7 \%, \mathrm{p}_{1-3}<0.05$ ). In the following terms of the experiment, the indicator increased statistically significantly with increasing severity of injury $\left(\mathrm{p}_{1-2}<0.05 ; \mathrm{p}_{1-3}<0.05 ; \mathrm{p}_{2-3}<0.05\right)$.

The use of Carbacetam for 7 days compared with animals without correction led to a statistically significantly lower content in the serum of the $\mathrm{MMM}_{254}$ fraction (Fig. 1) - by $25.4 \%(\mathrm{p}<0.05)$, after 14 days - by $33.9 \%$ ( $<<0.05)$. In turn, the content in the serum of the $\mathrm{MMM}_{280}$ fraction also decreased: after 7 days - by $21.3 \%(\mathrm{p}<0.05)$, after 14 days - by $24.0 \%(\mathrm{p}<0.05)$.

The obtained results indicate that ischemia-reperfusion of the limb is accompanied by a significant increase of the $\mathrm{MMM}_{254}$ fraction in the blood serum compared with the control from 1 hour of experiment with a maximum after 1 day and normalization of the index up to 14 days. The serum content of the $\mathrm{MMM}_{280}$ fraction in this group increased less. The indicator became significantly higher, from control only after 1 day with subsequent normalization in the following terms of the experiment.

Therefore, from the influence of pathogenic factors of the reperfused limb in the serum immediately increases the content of the $\mathrm{MMM}_{254}$ fraction. These include substances of low and average molecular weight (from 500 to $5000 \mathrm{Da}$ ), which, in addition to peptides, include about two hundred compounds of normal and abnormal metabolism [10]. It can be assumed that their early appearance is due to dysmetabolic disorders primarily in the ischemic limb. The maximum violations of the $\mathrm{MMM}_{254}$ fraction in the simulation of only ischemiareperfusion of the limb occurred after 1 day of the experiment. 


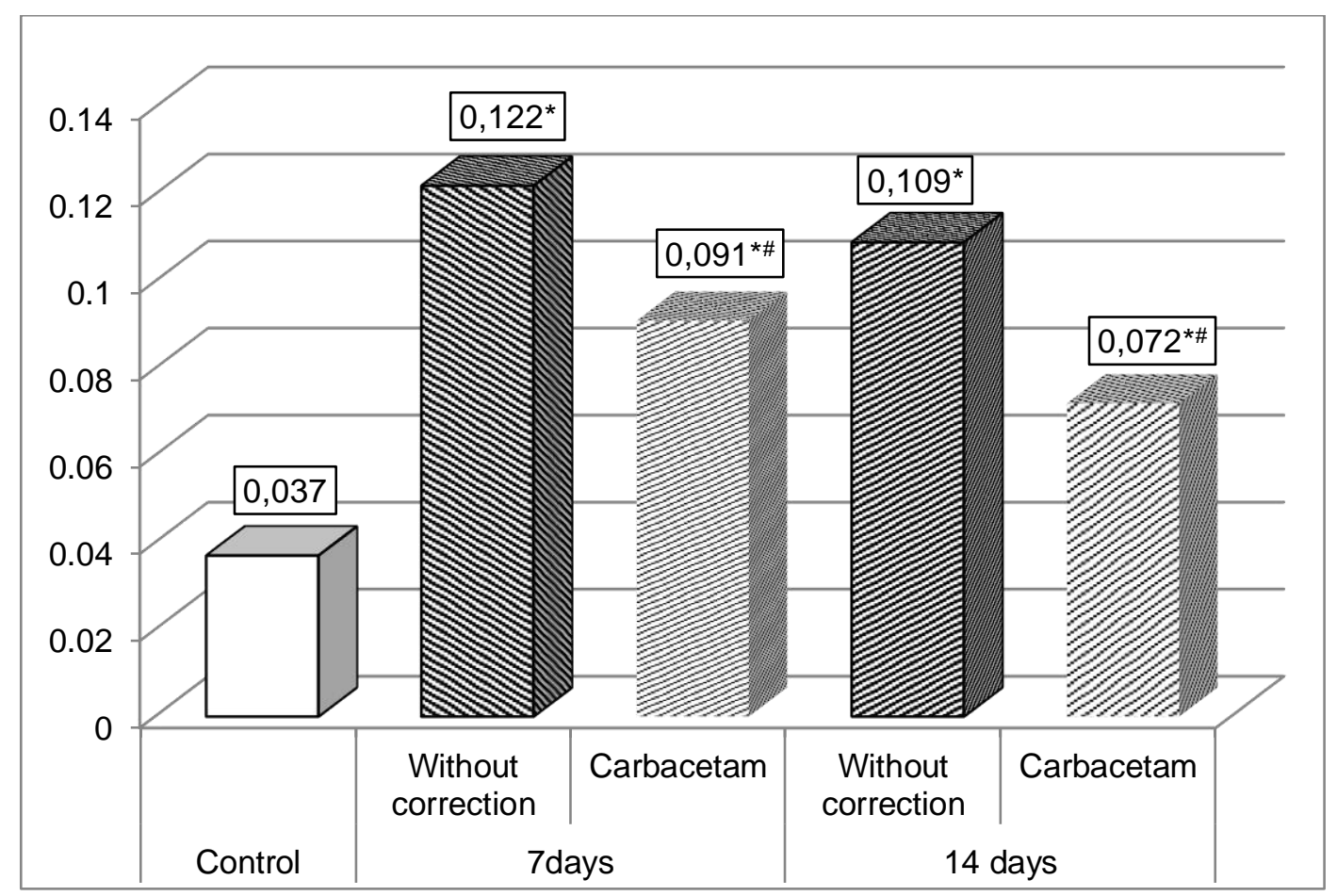

Figure 1 - The effect of Carbacetam on the content of $\mathrm{MMM}_{254}$ in the blood serum(conv.un.) after acute blood loss complicated by ischemia-reperfusion of the limb. (Note. Here and in Fig. 2: * differences in the control group are statistically significant, $\mathrm{p}<0,05 ;{ }^{\#}$ - differences for the group without correction are statistically significant, $\mathrm{p}<0,05$ ).

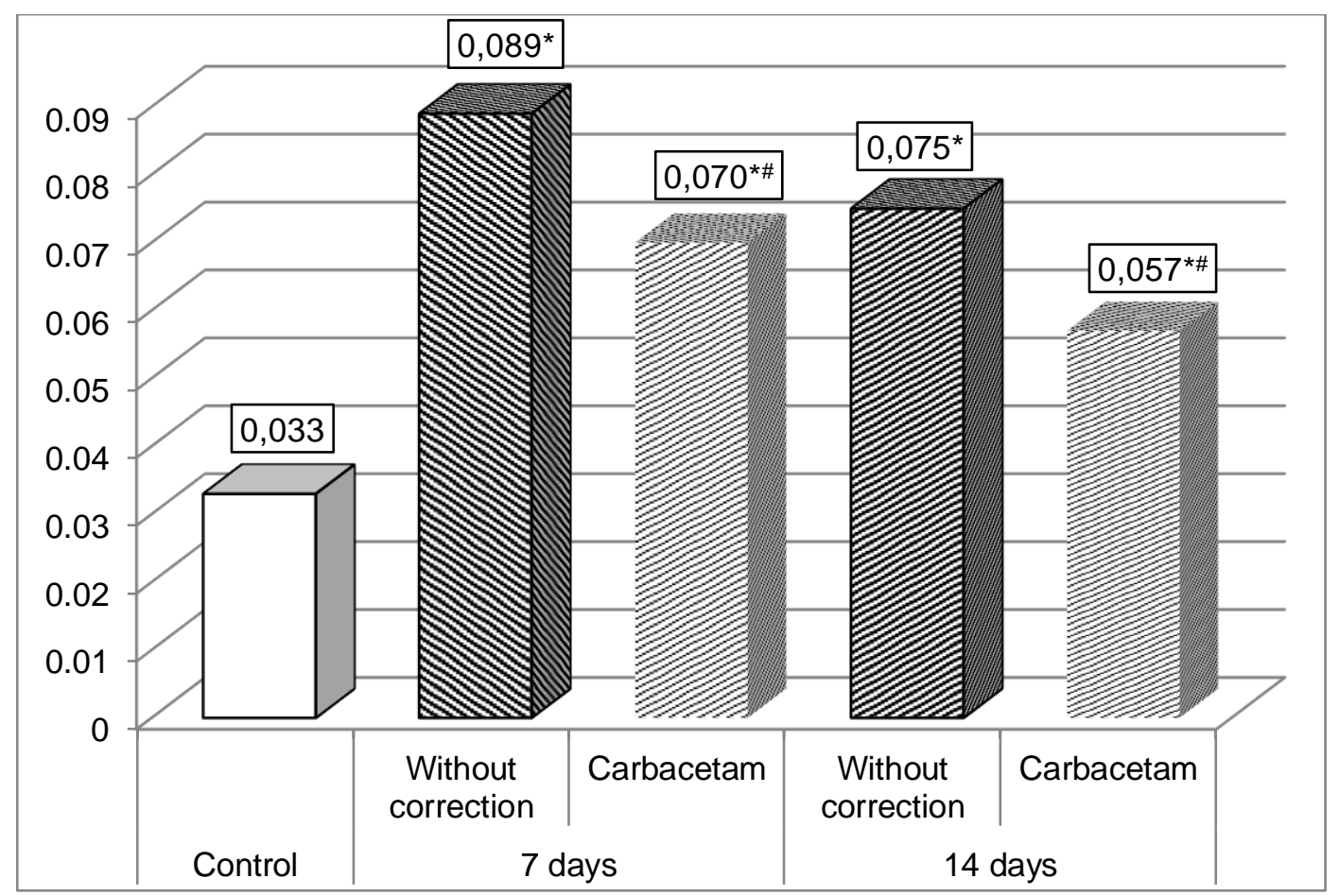

Figure 2 - The effect of Carbacetam on the content of $\mathrm{MMM}_{280}$ in the blood serum (conv.un.) after acute blood loss complicated by ischemia-reperfusion of the limb. 
During this period, the content of the $\mathrm{MMM}_{280}$ fraction also increased significantly, which reflects mainly the content of aromatic aminoacids and indicates severe metabolic disorders in the internal organs. Therefore, the strengthening of endotoxicosis after 1 day of the experiment under conditions of ischemia-reperfusion of the limb, probably due to systemic lesions with the development of multiorgan dysfunction. This assumption is confirmed by studies of some authors, who in modeling only ischemia-reperfusion of the limb in the internal organs observed an increase of lipid peroxidation [11] with the development of functional and metabolic disorders in the liver, kidneys and lungs [7, 12, 13]. It is important to note that in these experimental conditions, the detected violations decreased to 14 days of the experiment. This indicates that the detected disorders under the influence of two-hour limb ischemia in the reperfusion period are within homeostatic regulation and fully compensated by the body's defense systems.

After simulation of acute blood loss, both studied fractions of MMM increased from 1 hour of the experiment, reached a maximum after 1 day and did not return to the control level after 14 days. Thus, acute blood loss in the range of 20-22\% of circulating blood volume causes severe metabolic disorders in the internal organs with the appearance of abnormal synthesis of aromatic aminoacids, reduces the detoxification and excretory function of the internal organs. At the heart of the revealed disturbances, obviously lies the development of hemic hypoxia with formation active forms of oxygen, its negative impact on cell membranes and violation of membrane-dependent functions [14].

However, we found for the first time that two-hour ischemia-reperfusion of the limb significantly aggravates the course of acute blood loss, which revealed a significantly higher content in the blood serum of fractions $\mathrm{MMM}_{254}$ and $\mathbf{M M M}_{280}$ compared to other experimental groups in almost all periods of the experiment. It can be assumed that there is a layering of pathogenic mechanisms of limb ischemia-reperfusion and acute blood loss in the formation of endogenous intoxication syndrome. According to the some authors, endotoxicosis is considered one of the criteria for the severity of the lesion and the starting point for the development of multiorgan dysfunction [15].

Due to the use of Carbacetam, the content of both studied fractions of MMM in the blood serum compared with animals without correction was significantly reduced after 7 and 14 days of the experiment. Therefore, Carbacetam counteracts the mechanisms of formation the substances of low and average molecular weight and the formation of aromatic aminoacids, which is obviously due to antioxidant and membrane-stabilizing action [16]. Positive effect of Carbacetam on the functional state of the liver and kidneys in conditions of 
acute blood loss. complicated by ischemia-reperfusion of the limb was shown by other authors [7,8]. Although the studied parameters did not return to the level of the Carbacetam control group, it can be considered a promising pathogenetically justified means of reducing the level of endotoxicosis in the conditions of ischemia-reperfusion of the limb and acute blood loss.

Conclusions. 1. Simulation of limb ischemia-reperfusion is accompanied by the accumulation of $\mathrm{MMM}_{254-280}$ fractions with a maximum after 1 day of the experiment and normalization up to 14 days.

2. Acute blood loss in the range $20-22 \%$ of circulating blood volume causes an increase in the content in the serum of fractions $\mathrm{MMM}_{254-280}$ from 1 hour of the experiment, which up to 14 days do not reach the level of control. The detected disorders are significantly exacerbated after a combination of acute blood loss and ischemia-reperfusion of the limb.

3. The use of Carbacetam compared to animals without correction is accompanied by a significant decrease in the content of $\mathrm{MMM}_{254-280}$ fractions in the blood serum after 7 and 14 days of the experiment, which indicates the prospects of Carbacetam in the treatment of ischemic reperfusion syndrome and acute blood loss.

Prospects for further research. In the future it is advisable to study the features of liver detoxification function under the influence of acute blood loss and ischemia-reperfusion of the limb and evaluate the effectiveness of Carbacetam.

\section{References:}

1. Bulger E. M., Snyder D., Schoelles K. et al. (2014) An evidence-based prehospital guideline for external hemorrhage control: American College of Surgeons Committee on Trauma. Prehospital Emergency Care. no 18. pp.163-173.

2. Televiak A. T. (2018) Dynamika pokaznykiv perekysnoho okyslennia lipidiv ta antyoksydantnoho zakhystu $\mathrm{v}$ m'iazovii tkanyni zadnikh kintsivok shchuriv pry rozvytku ishemichno-reperfuziinoho syndromu (eksperymentalne doslidzhennia). [The dynamic of indicators of lipid peroxidation and antioxidant protection in muscle tissue of the hind limbs of the rats in development of the ischemic-reperfusion syndrome (experimental study).] Zdobutky klinichnoi i eksperymentalnoi medytsyny. no 3 (35). pp. 132-139. [in Ukrainian].

3. Clasper J. C., Brown K. V., Hill P. (2009) Limb complications following prehospital tourniquet use. J R Army Med Corps.. Vol. 155(3). pp. 200-202.

4. Van der Spuy L. (2012) Complications of the arterial tourniquet. South Afr J Anaesth Analg. Vol. 18 (1). pp. 14-18. 
5. Wright G., Mcdonald V. S., Smith V. G. (2015) Whould civilian pre-hospital emergency care provision include tourniquets for the management of uncontrolled traumatic haemorrhage. Australasian Journal of Paramedicine. Vol. 12 (4). pp. 1-5.

6. Horban I. I., Hudyma A. A., Maksymiv R. V.,. Antonyshyn I. V. (2020) Influence of two-hour tourniquets ischemia of limb and acute blood loss on systemic disorders of the body in the reperfusion period (experimental study). Wiadomości Lekarskie. Vol. LXXIII, Is. 7. P. 1330-1333. DOI: 10.36740/WLek202007104.

7. Shatskyi V. V., Hudyma A. A. (2019) Significance of lipid peroxidation processes in renal excretory dysfunction in cases of acute blood loss complicated by limb ischemiareperfusion and its correction. Journal of Education, Health and Sport. Vol.9, no 11., pp. $293-306$.

8. Horban I. I. (2020) Vplyv hostroi krovovtraty, uskladnenoi ishemiieiu-reperfuziieiu kintsivky, na antyoksydantno-prooksydantnyi balans pechinky ta yoho korektsiia karbatsetamom. [The effect of acute blood loss complicated by limb ischemia-reperfusion on the antioxidant-prooxidant balance of the liver and their correction by carbacetam.] Zdobutky klinichnoi i eksperymentalnoi medytsyny no 2., pp. 93-100. [in Ukrainian].

9. Andreichyn M. A., Bekh M. D., Demianenko V. V. et al. (1998) Metody doslidzhennia endohennoi intoksykatsii orhanizmu. [Methods of research of endogenous intoxication of an organism]: metodychni rekomendatsii. pp. 10-13. [in Ukrainian].

10. Kariakina E.V., Belova S.V. (2004) Molekuly srednei massy kak intehralnyi pokazatel metabolicheskykh narushenyi. [Molecules of average mass as an integral indicator of metabolic disorders.] obzor lyt. Klyn. lab. dyahnostyka. no 3., pp. 3-7. [in Russian].

11. Maksymyv R. V., Hudyma A. A., Sydorenko V. M. (2017) Dynamika balansu antyoksydantno-prooksydantnykh mekhanizmiv u vnutrishnikh orhanakh pid vplyvom arterialnoho dzhhuta i reperfuzii kintsivky. [Dynamic of balance of antioxidant-prooxidant mechanism in internal organs under the influence of the arterial tourniquet and limb reperfusion.] Shpytalna khirurhiia. Zhurnal imeni L. Ya. Kovalchuka. no 1., pp. 37-44. [in Ukrainian].

12.. Horban I. I., Hudyma A. A., Pasichnyk M. A., Antonyshyn I. V. (2020) The role of mandible injury in the pathogenesis of biochemical and functional liver disorders caused by acute blood loss and two-hour ischemia of limbs, and the efficiency of their correction by carbacetam. Journal of Education, Health and Sport. Vol. 10, no 8., pp. 570-588. DOI http://dx.doi.org/10.12775/JEHS.2020.10.08.069 
13. Stakhiv O. V., Maksymyv R. V. (2020) Vplyv hostroi krovovtraty, uskladnenoi ishemiieiu-reperfuziieiu kintsivky, na aktyvnist protsesiv lipidnoi peroksydatsii u leheniakh ta yikh korektsiia karbatsetamom. [Influence of acute blood loss complicated by limb ischemiareperfusion on the activity of lipid peroxidation processes in lungs and their correction with carbacetam.] Visnyk medychnykh i biolohichnykh doslidzhen. no 3 (5)., pp. 108-114. [in Ukrainian].

14. Jeremy W. (2018) Hemorrhagic Shock. The New England Journal of Medicine. Vol. 378, no 4., pp. 370-379.

15. Ziablytsev. S.V., Korovka S. Ya., Chernobryvtsev P.A. (2013) Mekhanizmy i kliuchevye zvenia razvytyia syndroma endohennoi intoksykatsyy pry cherepno-mozghovoi travme [ Mechanisms and key links in the development of endogenous intoxication syndrome at a craniocerebral trauma.] Mizhnarodnyi visnyk medytsyny. Vol. 6, no.1., pp. 18-23. [in Russian].

16. Kozak D. V. (2014) Vplyv karbatsetamu na antyoksydantnyi-prooksydantnyi balans tkanyny sertsia, lehen i pechinky $\mathrm{v}$ dynamitsi politravmy. [Effect of carbacetam on antioxidant and prooxidant balance of heart, lungs and liver tissues in polytrauma dynamic]. Shpytalna khirurhiia. no 1(65)., pp. 40-42. [in Ukrainian]. 